\title{
DEVELOPMENT OF VALUE CHAIN STRATEGY OF SEA TRANSPORT SERVICES' COMPANIES AFTER SPIN OFF
}

\author{
Liliyani Nurul Winda*, Harianto, Safari Arief \\ School of Business, Bogor Agricultural University, Indonesia \\ *E-mail: nurulwindaliliyani@ymail.com
}

\begin{abstract}
This research is intended to provide an alternative strategy that can be applied to PT. DWM as a company that has made a spin off by analysing the value chain, then analysing internal and external factors. This type of research uses descriptive methods supported by interviews semi structured to obtain the data used. In determining informant used technique purposive sampling. In preparing alternative strategies in this research used SWOT analysis. The results of this research indicate that the position of the company is currently on the stage of growing and building, so the company must implement the right strategy to run the business.
\end{abstract}

\section{KEY WORDS}

Development, external factors, internal factors, strategy, value chain.

Indonesia is an archipelagic country that connected by sea between its islands. It can be said that the sea is not a separator but unites various islands and regions in Indonesia. As the largest archipelago country in the world and two-thirds of its territory is water, Indonesia needs sea transportation in sufficiently large quantities to support the distribution of goods and for passenger mobilization. It cannot be denied that the means of sea transportation in island countries such as Indonesia have become the backbone of the large scale movement of goods distribution.

Based on the annual report of the Indonesian Ministry of Transportation sea freight load has increased every year, that is 5.736 GT in 2013, 9.722 GT in 2014, 10.531 GT in 201537.666 GT in 2016, the last national fleet of 27.564 vessels containing 40.800 GT. This makes the opportunities available for companies engaged in the field of sea transportation services considered quite large and promising, can be seen from the development of marine transportation business in Indonesia which also experienced growth. Increasing the business of sea transportation services from year to year can be seen in table 1, this causes a mature strategy must be prepared so that the company can continue to grow following the flow of environmental change.

Table 1 - Development of the National Sea Transport Company 2013-2017

\begin{tabular}{cccccc}
\hline Year & 2013 & 2014 & 2015 & 2016 & 2017 \\
\hline The number of sea freight companies & 2.442 & 2.718 & 2.811 & 2.896 & 3.130 \\
Percentage Increase & 11,39 & 3,42 & 3,03 & 3,02 & 8,08 \\
\hline
\end{tabular}

The development of the company and the increase in sea freight load are not in line with the decreasing level of safety due to lack of staffing from related parties, as evidenced by several accidents that occurred. The problem in other sea transport industries is licensing. The Indonesian Ministry of Transportation is evaluating thousands of sea transportation business licenses; this is due to many companies whose business activities move from the core business.

The current conditions and data make a company engaged in sea transportation service in Indonesia must be able to prepare the right strategy to be able to address the existing situation. One of the companies engaged in the sea freight service industry is PT. DWM located in Jakarta Indonesia. This company has just done a spin off or just separated itself from its holding company. While still joining the holding company and those located in Sulawesi, the company only carried food transportation because the company was 
surrounded by offshore drilling sites. The company currently has the main focus of providing services to all partners and customers with the best quality services. PT. DWM sees opportunities in market niches that many large companies have not yet entered. In 2017, transportation schedules of various types of goods such as sand and wood are moved by PT. DWM is still relatively small, it can even be said to be said to be below the average when compared to the transport data of the transportation ministry.

According to Khonama (2015) in his journal, even though so far there have been no services or other goods that can replace sea transportation services, the company must remain vigilant with all changes by continuing to develop. One solution of the current sea transportation service industry is that companies must improve their quality to be more optimal. The way that can be done is to pay attention to the interaction between the value chain that exits within the company itself, because if one value chain fails to provide service it will affect other chains. This due to that fact that the characteristics of service products are interrelated and not visible. Mapping internal and external factors in the value chain environment can be used to formulate future development strategies based on the value chain approach.

\section{LITERATURE REVIEW}

The research entitled Development of Chain Analysis Applications for the Value of Gray Fabric Products in Textile Companies was carried out by Sonia and Julia in 2017. This study aims to identify each primary activity and the value chain support activities of gray cloth products within the company. SWOT method is used where at the initial stage identification of primary and supporting activities is carried out by value chain mapping, this data is obtained from the results of observation in the field through interviews and viewing company records. The data that has been obtained is then used in the SWOT analysis. The results of this study state that each value chain in the company both primary activity and supporting activities, are interconnected so that it effects the success of a company. Based on the results of the SWOT analysis, the results of procurement activities obtained such as the selection of suppliers of raw materials need to be considered so that the company can continue to grow.

Business Development Strategy Analysis at PT. Citra Abadi Trans is a research conducted by Cornellius in 2017. This research was conducted in East Java, with the products. This research was carried out in East Java, with the products exported by the company under investigation in the form of freight forwarding services. This research was made with the aim to describe the internal and external environmental conditions that are occurring in the company and develop a business development strategy. The method used in this study is a SWOT analysis. The type of research used in this study is qualitative with the data collection techniques used are semi structured interviews. The data obtained is then analyzed and a SWOT matrix is formed to be able to formulate a number of alternative strategies for the company. This study states that the number of customers and increase the frequency of services use with internal and external environmental analysis.

Samekto in his research entitled improving the Performance of Marine Vessel Expedition Companies Through Business Diversification, using descriptive methods. The research data was obtained through in depth interviews with directors and several employees. The research pays attention to every aspect of all activities carried out by the company from upstream to downstream with consideration of internal and external factors. The purpose of this research is that companies can provide optimum services, this can be achieved through developing strategies. The results of this study state that companies tend to focus on the upstream part of the activity, namely the sales department without regard to the changes in regulations and legislation it is necessary to integrate all activities and to determine the superiority of the company.

The research of Palm Sugar Value Chain is a study written by Maria et al in 2016. The purpose of this research is to identify sugar palm value chain in Tomohon City. This research is a case study for farmers in Tomohon in order to survive for the long term and needs 
development. Value chain analysis is done to find out activities that produce additional value. SWOT analysis to identify various factors systematically. This study states that on the average value involves many actors from all activities, therefore integration of each activity are needed in order to increase production capabilities accompanied by creativity to market the product.

Value chain analysis on CV Master Sentra Boga, is a research conducted by Hadiwidjojo conducted in 2016 in Surabaya. This study aims to analyze business activities carried out by the company which consists of the main activities and supporting activities to compile the value chain from CV Master Sentra Boga. This study uses a descriptive method with a qualitative approach. The data used are primary data obtained from interviews and secondary data by looking at existing archives.

Competitiveness of PT. Benar Flora Utama based on Floricultural Value Chain Activities is the research title written by Kurniaty at all in 2012. The purpose of this study is to identify the value chain to describe internal and external conditions as a factor of company analysis, then determine the company's strategic position and formulate strategies to improve competitiveness. This study uses a SWOT analysis to produce alternative strategies that can be proposed to the company. The results of this study state that by strengthening the applied value chain the company is useful to maintain the company's business in its main industry. Each value chain activity has resources and capabilities that support so that existing activities can be carried out effectively and efficiently. The final results of this study state that the main and supporting activities in the company are equally important and support each other.

The use of the SWOT and AHP methods was used by Setiawati in 2017 with the research title Competitive strategies of shipping companies and shipyards as a result of the weakening of coal business in Indonesia. In this study an analysis of several shipping companies and shipyard companies was able to survive and compete in winning and through difficult conditions. Strategy is the key to success in competition in the midst of a rapidly changing business environment. The ship industry itself needs a strategy that can create a competitive advantage because it has the characteristics of industries that compete globally. Sources of data from this study include primary data which in this study are top management of shipping companies and shipyards that are directly involved and secondary data in the form of annual reports, industry publications and analysis by the media. The data is then processed using a SWOT analysis that produces strengths, weaknesses, opportunities and threats. Then a combination of SWOT and AHP methods was carried out to support strategic decision making. And the results of the study state that all companies carry out defensive strategies that make them shipping companies that can survive until now.

\section{METHODS OF RESEARCH}

This research was conducted at PT. DWM located at Jalan Utan Kayu Rawamangun, South Jakarta. This research was conducted in the field for 4 months, namely March-June 2018, in March fact finding was conducted and April-June was conducted in depth interviews to determine priority strategies. This research will begin by conducting a value chain mapping by collecting data following the research stages based on a framework of thought. First, identify the value chain of PT. DWM through descriptive analysis. Descriptive analysis is used to describe the general picture of each value chain member selected based on the results of the survey and the results of in depth interviews with expert respondents. Value chain analysis besides being used for profile descriptions, it also describes forms of cooperation both forward and backward and looks at the interrelationships between one value chain and another.

The next stage is the identification of internal factor use Internal Factors Evaluation (IFE) matrix and external factors use External Factors Evaluation (EFE) matrix that will show strengths and weaknesses as internal factors, as well as opportunities and threats as external factors, each of which will be weighted. The total weight scores obtained from each division form the composition of the IE matrix at the company level. The IE matrix can be 
divided into three major parts which have different strategy implications (David 2011). First, the provisions for companies included in cells I, II, or IV can be described as growing and building. Secondly, companies that are included in cells III, V, or VI can be handled properly through a hold and maintenance strategy. Third, for companies included in cells VI, VIII, or IX are harvests or divestments. The WO strategy, this strategy is based on utilizing existing opportunities by minimizing existing weaknesses, this strategy supports the strategy of turning around. Last, WT strategy this strategy is based on defensive activities and tries to minimize existing weaknesses and avoid threats, this strategy supports defensive strategies.

The formulation of alternative strategies is made using SWOT analysis and producing the right decisions must go through three stages, namely the data collection stage, the data analysis stage, and finally the decision making stage. This matrix starts from summarizing information, by entering basic information on the results of the IFE and EFE The strategy is made in the form of a SWOT matrix by generating the possibility of four alternative sets of strategies, namely the SO strategy, this strategy is made by utilizing all the strengths to seize and utilize the opportunities as much as possible and support aggressive strategies. Furthermore, the ST strategy, this strategy is made by using the power that is owned to overcome threats, this strategy supports the diversification strategy (Marimin 2004).

Planning of Silk Fabric Woven Business Development Strategy with Balanced Scorecard Method Approach (Case Study in Tiga Putra Silk Factory) which was a study conducted by Aulia and Ikhwana in 2012. The purpose of this study is to identify the internal and external factors of the company as well as formulate and plan development strategies in an effort to obtain many business relationships and add value to profitability for the company with one of its methods, namely the External Internal (IE) matrix. IE matrix is used to find out the position of the company before determining what strategy to choose. The results of this study say if the company is in a low market share position but must compete in industries with high growth, the company must pay attention to many small things that can be a gap to develop its business.

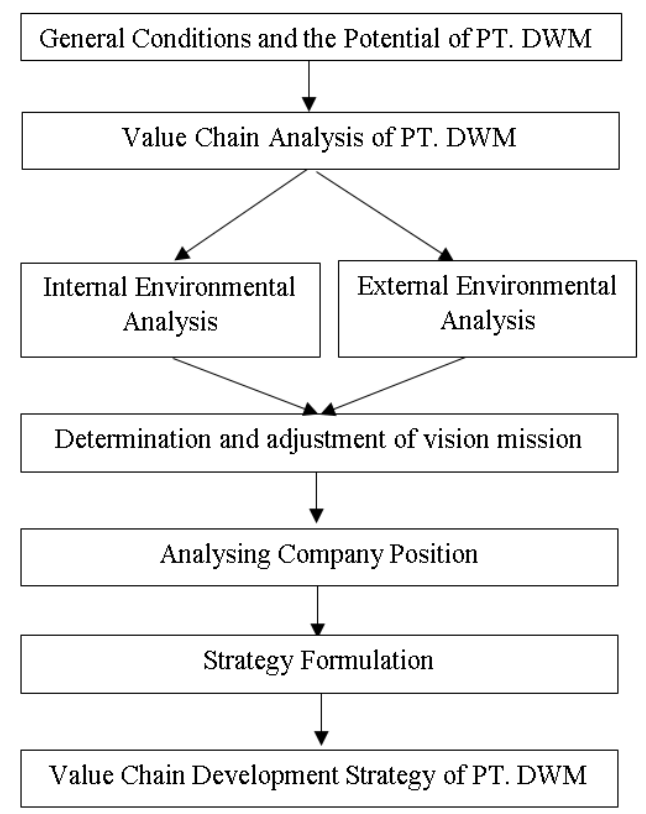

Figure 1 - Conceptual Framework of the Research

\section{RESULTS AND DISCUSSION}

PT. DWM is a company newly established in 2016 . The main focus of this company is to provide services to all partners and customers with the best quality services. With agents and partners spread across major cities in Indonesia, the company is currently working on shipping services with Door to Door, Port to Port, Door to Port and Port to Door systems. 
This company has a vision become a leading supply company by prioritizing customer and partner satisfaction through good service and product quality. This vision statement shows the company's strategic direction to achieve various results in the future so that it will guide the deployment of company resources for achieving these goals.

As a company that has just been established, of course it is not easy to get involved in the sea transport service business. Companies must set goals to be more focused and directed. After determining the target, the company must make a strategy in order to reach the goals. The way that can be done is to pay attention to the interactions between the value chains that exist within the company itself, because if one value chain fails to provide service it will affect other chains. This is due to the fact that the characteristics of service products are interrelated and not visible. Mapping internal and external factors in the value chain environment can be used to formulate future development strategies based on the value chain approach.

Value Chain Activities. Every company is a set of activities carried out to design, create, market, deliver and support its products (Porter 2007). In the value chain a company is divided into two, the main activities are main and supporting activities and general description of the company's value chain can be seen in figure 2. Inbound logistics, operation and outbound logistics activities are key activities of PT. DWM this activity includes the process of receiving and managing goods to be transported by the company from the receipt from the supplier to the receipt of goods to the customer. The advantages possessed by PT. DWM is a variety of services offered and has its own set of ships consisting of tugboats and barges which can reduce operational costs, and other advantages are in the supply of sand because the company has its own mine. On the other hand the weaknesses in this company are based on the lack of Human Resources having a background in the field of transportation. As a newly established service company, human resources are needed in a not small amount.

\begin{tabular}{|c|c|c|c|c|}
\hline \multicolumn{2}{|l|}{ Firm Infrastructure } & \multicolumn{3}{|c|}{ General management } \\
\hline \multicolumn{2}{|c|}{ Technology Development } & \multicolumn{3}{|c|}{ Develop and Improve Information, Communication and Quality } \\
\hline \multicolumn{2}{|c|}{ Human Resources Management } & \multicolumn{3}{|c|}{ Recruiting, Developing, Employees and Marketing Policies } \\
\hline \multicolumn{2}{|l|}{ Procurement } & \multicolumn{3}{|c|}{ Purchasing, Expediting, Traffic } \\
\hline $\begin{array}{l}\text { Inbound Logistics } \\
\text { Fuel, Logistics, } \\
\text { Spare Parts, Receipt } \\
\text { of goods to be sent }\end{array}$ & $\begin{array}{c}\text { Operations } \\
\text { Sand Mining } \\
\& \\
\text { Transportation } \\
\text { of Goods }\end{array}$ & $\begin{array}{l}\text { Outbound Logistics } \\
\text { Goods received by } \\
\text { costumers }\end{array}$ & $\begin{array}{l}\text { Marketing and Sales } \\
\text { Outturn Report, } \\
\text { Promotion, Looking } \\
\text { for partners }\end{array}$ & $\begin{array}{c}\text { Service } \\
\text { After Sales Service }\end{array}$ \\
\hline
\end{tabular}

Figure 2 - Value Chain of PT. DWM

Internal and External Environmental Analysis. At this stage, the identification using Internal Factor Evaluation (IFE) produces strengths and weaknesses and External Factor Evaluation (EFE) which will produce opportunities and threats, then each will be given a weight and in this study summarized in table 2 these factors are obtained from the results of filling out the questionnaire. After being analyzed as a newly established company, PT DWM still has many weaknesses but on the other hand the company already has the power to distinguish it from other similar companies.

Factor (S1) that is having its own IUP with the KSO system. After weighting is repeated and comparing with other factors, experts give a weight of 0.15 and rank 4.00. The Cooperation System Operations (KSO) is the first party agreement as the land owner. He is willing to cooperate with the second party as the capital owner who wants to capitalize on the first party to exploit the excavated land within the first party's production operations. Experts assess the ownership of assets will be long-term because the exploited minerals will run out but not in the near future. 
Factor (S2) has 3 sets of ships. The experts gave back the weights and ratings for these factors 0.13 and 3.00 respectively. Ownership of a complete set of ships is important because with the presence of ships, of course, no additional costs are needed to rent a boat for the transportation process. The experts consider the ship to be an asset with a long duration, the ship can be used for quite a long time, but if the condition of the engine and other conditions are considered quite old, the ship must be replaced with the younger one.

Factor (W1) the fleet owned by the company still cannot meet customer demand weighed 0.09 and ranked 3.00 by experts. This factor is considered to inhibit the increase in sales made by the company and has medium-term duration for the company. To cover the shortage of ships this company leased a set of ships to meet costumers demand, because to buy a new set of ships need a lot of money.

Table 1 - EFE \& IFE Matrix

\begin{tabular}{|c|c|}
\hline External Factors Evaluation (EFE) & Internal Factors Evaluation (IFE) \\
\hline Opportunities & Strengths \\
\hline Demand for increased construction raw materials & Having its own IUP with the KSO system \\
\hline Trend of rising sand prices & Have 3 sets of ships \\
\hline Threats & Weakness \\
\hline $\begin{array}{l}\text { Current economic developments make the risk of } \\
\text { bad debts }\end{array}$ & $\begin{array}{l}\text { The fleet owned by the company still cannot meet } \\
\text { customer demand }\end{array}$ \\
\hline Inadequate infrastructure and complicated & Limited stockpile conditions in ports \\
\hline regulations at the port & $\begin{array}{l}\text { The operating routes are still limited } \\
\text { Not yet doing ISO } 9000 \text { certification }\end{array}$ \\
\hline
\end{tabular}

The next factor (W2) is that the stockpile conditions in the limited port are given weights and ratings by experts, namely 0.085 and 2.0. This factor is considered by experts to cause a high waiting time in the port and delay in the time the item is received by the customer and given a short duration because it can be overcome by ordering the stockpile in advance before the goods arrive.

In factor (W3) the operating route which is still small is given a weight of 0.075 and a rating of 3.00. This factor is still related to the condition of the company still unable to meet customer demand and to expand the market to new areas. Next, factor (W4) is that it has not yet carried out certification of services by referring to the ISO 9000 system. Experts give repeat weights and ratings for this factor of 0.12 and 3.00 respectively. This factor is related to the company's image which is identical with good quality and speed in carrying out the procedure.

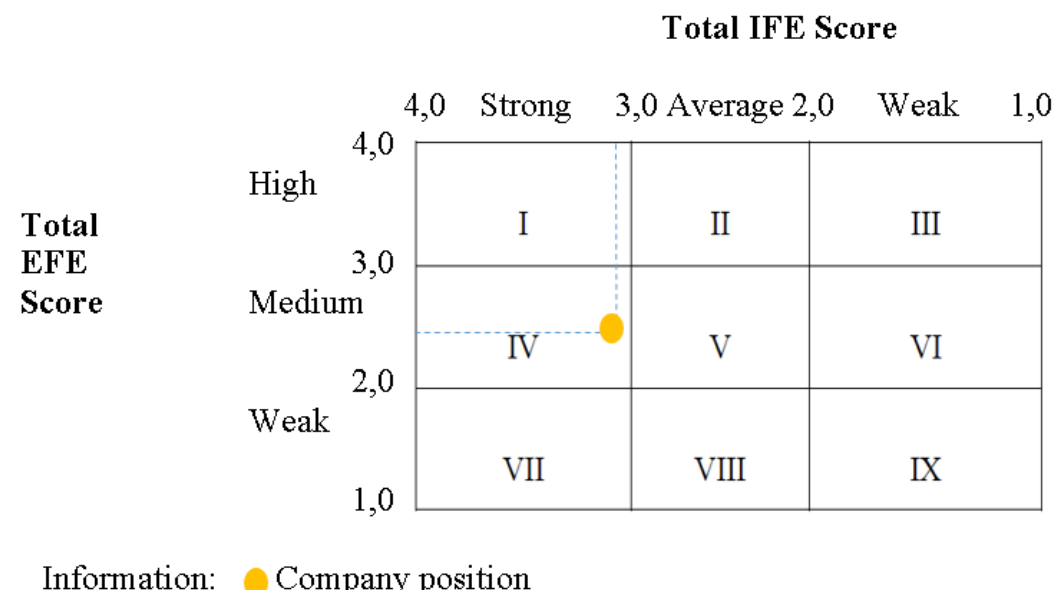

Figure 3 - Company position in the IE matrix

Internal External Matrix (IE). The IE matrix is useful for positioning a company into a matrix consisting of nine cells (Umar 2001). IE matrix is based on two dimensions namely the total IFE weighting score on the $\mathrm{X}$ axis and the total EFE weighting score on the $\mathrm{Y}$ axis. 
Based on the results of the previous weighting, the IFE matrix obtained a total weighted value of 2.9 while the total weighted value of the EFE matrix was 2.445. Based on the results of the two plots matrixed into the IE matrix image, it is known in figure 3 that the position of PT. DWM is in quadrant IV. The strategy chosen in quadrant IV is grow and build strategy which is an intensive strategy where (Market Penetration, market development and product development) and integrated strategies (backward integration, forward integration and horizontal integration). In this strategy, it is recommended that PT. DWM builds its competitive position to be better than its competitors; the types of products that are varied and tailored to the needs of buyers can improve the company's competitive position compared to similar companies.

SWOT Analysis. SWOT analysis is used to identify various factors systematically to formulate a strategy (Freddy 2002). Experts use SWOT analysis to formulate appropriate priority strategies to overcome the problems faced by PT. DWM. The SWOT analysis in this company is listed in table 3.

Table 3 - PT. DWM SWOT Matrix

\begin{tabular}{|c|c|c|}
\hline EFE & $\begin{array}{l}\text { Strengths } \\
\text { (S1) Having its own IUP with the } \\
\text { KSO system; } \\
\text { (S2) Have } 5 \text { sets of ships }\end{array}$ & $\begin{array}{l}\text { Weakness } \\
\text { (W1) The fleet owned by the company still } \\
\text { cannot meet customer demand; } \\
\text { (W2) Limited stockpile conditions in ports; } \\
\text { (W3) The operating routes are still limited; } \\
\text { (W4) Not yet doing ISO } 9000 \text { certification }\end{array}$ \\
\hline $\begin{array}{l}\text { Opportunities } \\
\text { (O1) Demand for } \\
\text { increased construction } \\
\text { raw materials; } \\
\text { (O2) Trend of rising } \\
\text { sand prices }\end{array}$ & $\begin{array}{l}\text { Strategy-SO } \\
\text { Optimizing the transportation } \\
\text { business and supplying sand for } \\
\text { construction purposes on toll roads } \\
\text { and building construction } \\
\text { (S2,O1,O2); } \\
\text { Utilizing IUP with a product } \\
\text { development strategy }(\mathrm{S} 1, \mathrm{O} 1, \mathrm{O} 2)\end{array}$ & $\begin{array}{l}\text { Strategy-WO } \\
\text { With the Market development strategy, } \\
\text { certifying ISO } 9000 \text { and the number of fleets is } \\
\text { increased by } 2 \text { sets for the distribution of goods } \\
(\mathrm{W} 1, \mathrm{~W} 3, \mathrm{~W} 9 . \mathrm{O} 1, \mathrm{O} 2) \text {; } \\
\text { Menyewa stockpile di pelabuhan yang dituju } \\
\text { (W2,W3, O1,O2) }\end{array}$ \\
\hline $\begin{array}{l}\text { Threats } \\
\text { (T1) Current economic } \\
\text { developments make } \\
\text { the risk of bad debts; } \\
\text { (T2) Inadequate } \\
\text { infrastructure and } \\
\text { complicated regulations } \\
\text { at the port }\end{array}$ & $\begin{array}{l}\text { Strategy-ST } \\
\text { Make a long-term cooperation } \\
\text { contractS1,S2, T1,T2); } \\
\text { Make cash payments for spot deals } \\
\text { with market penetration strategies } \\
(\mathrm{S} 1, \mathrm{~S} 2, \mathrm{~T} 1, \mathrm{~T} 2)\end{array}$ & $\begin{array}{l}\text { Strategy-WT } \\
\text { With Market Development strategy, make } \\
\text { costumer selection (W1,W2,W3,T1); } \\
\text { Start a long-term cooperation program with } \\
\text { both customers and partners } \\
\text { (W1,W2,W3,W4,T1,T2) }\end{array}$ \\
\hline
\end{tabular}

In this analysis a situational comparison analysis will be carried out in a matrix, where experts will formulate a strategy based on a comparison between the strengths of opportunity (SO), threat strength (ST), opportunity weakness (SO), threat weakness (WT). The SO strategy is based on existing factors by utilizing strengths (S1 \& S2) to seize and take advantage of opportunities (O1 \& $\mathrm{O} 2$ ) as much as possible. Two strategies were obtained, first to optimize the transportation business because it has its own set of ships and supply sand for construction purposes on toll roads and building construction $(\mathrm{S} 1, \mathrm{O} 1, \mathrm{O} 2)$ and the second strategy by utilizing IUP because of the increasing raw material demand and the price of sand competitive with product development (S2, O1, O2).

The next strategy ST uses all the strengths ( $S 1$ \& S2) that the company has to overcome threats (T1 \& T2). By considering the existing strengths and threats, two strategies are generated, the first being a long-term cooperation contract. The second strategy is made for companies that do not want to carry out long-term contracts so they can make cash payments for spot deals based on market penetration strategies. This collaboration is carried out to facilitate the bureaucratic system and prevent bad credit.

WO strategies based on opportunity utilization (O1 \& $\mathrm{O} 2$ ) exist by minimizing weaknesses (W1, W2, W3 \& W4). There are two strategic market development results, namely ISO 9000 certification and increasing the number of fleets as many as 2 sets for the 
distribution of goods (W1, W3, W9, O1, O2). The second strategy is to rent stockpiles in the destination port (W2. W3, O1, O2).

The final strategy is WT, this strategy is based on defensive activities and seeks to minimize weaknesses (W1, W2, W3 \& W4) and avoid threats (T1 \& T2). The strategy generated is to conduct customer selection (W1, W2, W3 \& T1). The second is the strategy of starting a long-term cooperation program with both customers and partners (W1, W2, W3, W4, T1 \& T2) with a market development strategy.

\section{CONCLUSION}

Judging from its value chain activities, the company has advantages in the operations section. The ownership of mine land and a complete set of ships is what distinguish PT. DWM with similar companies. On the other hand, as a company that just did spin off, PT. DWM has a weakness in the human resources field because more employees are needed as driving companies. The company's current positions when viewed from the Internal External matrix are grown and build position. After knowing the position of the company, elaboration of internal and external factors, several alternative strategies were produced, then weighted which resulted in a priority strategy taking into account the company's financial condition. At PT. This DWM president director plays an important role, in determining the strategy to be in accordance with the company's goals, namely to increase profits.

\section{RECOMMENDATIONS}

After experiencing a spin off, the president director of PT. DWM needs to have a stronger commitment to develop the company, because it has an important role in making various decisions. It is expected that the company can conduct ISO certification in the near future because it will greatly affect the company's image. In addition, finding investors is good enough so that the company can continue to grow and implement all the recommended strategies. In this study there are various limitations, so it is expected that in the next study can make interrelated analysis between the strategies produced.

\section{REFERENCES}

1. Aulia, D. and Ikhwana, A., 2013. Perencanaan strategi pengembangan usaha kain tenun sutra dengan pendekatan metode balanced scorecard (studi kasus di pabrik Sutra Tiga Putra). Jurnal Kalibrasi, 10(1).

2. Cornellius, Dandy. 2017. Analisis Strategi pengembangan Bisnis pada PT. CITRA ABADI TRANS. AGORA. 5(1). 1-10.

3. David, FR. (2011). Strategic management: Concept and cases. Thirteenth edition. Boston (US): Prentice Hall Inc.

4. Hadiwidjojo, C.C. 2016. Analisis Rantai Nilai Pada CV Master Sentra Boga. Agora, 4(1), pp.51-59.

5. Kristina Sonia, Gunawan Julia. 2017. Pengembangan Aplikasi Analisis Rantai Nilai Produk Kain Gray di Perusahaan Tekstil. Jurnal Telematika. 12(1).1-9.

6. Kurniaty, R.M., 2011. Analisis daya saing pt. benar flora utama berdasarkan aktivitas rantai nilai florikultura (Doctoral dissertation, Institut Pertanian Bogor).

7. Lasse, D.A. 2015. Manajemen Bisnis Transportasi Laut, Carter, dan Claim. Jakarta (ID): PT Raja Grafindo Persada.

8. Laasse, D.A. 2012. Manajemen Muatan, Aktivitas Rantai Pasok di Daerah Pelabuhan. Jakarta (ID): PT Raja Grafindo Persada.

9. Leonard Khonama. 2015. Strategi Pengembangan Usaha Angkutan Laut Pada PT. Samudra Bahari Utama di Surabaya. AGORA. 3(1). 1-6.

10. Marimin. 2004. Teknik dan Aplikasi Pengambilan Keputusan Kriteria Majemuk. Jakarta (ID): PT Grasindo. 
11. Porter, M. E (2007). Strategi Bersaing: Teknik Menganalisa Industri dan Pesaing. (Sigit Suryanto, Trans.) Tangerang: Kharisma Publishing Group.

12. Sampit, M.M., Kindangen, P. and Wullur, M. 2016. Analisis Rantai Nilai Gula Aren (Studi Kasus Pada Petani Nira Di Tomohon). Jurnal EMBA: Jurnal Riset Ekonomi, Manajemen, Bisnis dan Akuntansi, 4(3).

13. Samketo, Agus Aji. Soejanto. 2014. Meningkatkan Kinerja Perusahaan Ekspedisi Muatan Kapal Laut Melalui Diversivikasi Usaha. Jurnal Manajemen Transportasi dan Logistik. 1(1). 1-14.

14. Setiawati, R. 2018. Strategi Bersaing Perusahaan Pelayaran Dan Galangan Kapal Sebagai Efek Lesunya Bisnis Batu Bara di Indonesia. Jurnal Manajemen Transportasi \& Logistik. 4(3). 287-302.

15. Umar H. 2001. Strategic Management in Action. Jakarta (ID): PT Gramedia Pustaka Utama. 